\title{
Potential Impacts of Sea Level Rise on the Coasts of Turkey
}

\author{
Sümeyra KURT ${ }^{1 *} \quad$ Xingong $\mathrm{LI}^{2}$ \\ 1. Visiting scholar, University of Kansas, College of Liberal Arts and Sciences - Geography and Atmospheric \\ Science, Kansas, USA. \\ 2. Prof., University of Kansas, College of Liberal Arts and Sciences - Geography and Atmospheric Science, \\ Kansas, USA.
}

\begin{abstract}
The reasons like global warming and climate change cause changes in sea and lake levels in addition to natural and human factors, on the other hand, they induce major changes in coastal region. The spatial and temporal tracing, monitoring and evaluation of these changes taking place in the coastal areas are of great importance in terms of presenting the environmental, economic and social issues that may arise in the future. Changes in sea levels in the coasts of Turkey were examined in this study. The risky areas that would be flooded due to sea level change were identified by using spatial analysis at Geographic Information Systems (CBS). About 3\% of Turkey's coasts consist of low-altitude coastal areas. It can be noticed by looking at the sea level rise scenarios that the coastal cities are under threat. According to the sea level change scenarios in coastal cities in Turkey, the ratio of the area affected by the water level changes in Adana $\left(13844 \mathrm{~km}^{2}\right)$, Izmir $\left(11891 \mathrm{~km}^{2}\right)$, Samsun $\left(9725 \mathrm{~km}^{2}\right)$, and Edirne $\left(6145 \mathrm{~km}^{2}\right)$ provinces that have low-elevation terrain and large delta areas seems to be more than other cities. Considering the fact that the high proportion of the population density in Turkey is in coastal areas such as the Mediterranean, the Marmara, the Aegean and Black Sea regions; in the face of a possible sea level rise, it is necessary to determine the factors that will be exposed to physical dangers in the cities and the areas vulnerable to these kinds of dangers by identifying the current situation of the coastal cities.
\end{abstract}

Keywords: Sea Level Rise, Coasts of Turkey, Geographic Information Systems (GIS).

DOI: $10.7176 / \mathrm{JEES} / 10-5-04$

Publication date:May $31^{\text {st }} 2020$

\section{Introduction}

One of the most significant environmental issues that the coastal areas encounter is the increase in sea levels as a result of global climate changes and their physical effects. Global warming or climate change is a global issue in terms of its causes and effects. This problem was highlighted in the last evaluation report of the Intergovernmental Panel on Climate Change (IPCC). It was stated in the report that the global sea level in the 20th century increased by an average of $1.7 \pm 0.5 \mathrm{~mm}$ per year and the increase was accelerated especially after the $1990 \mathrm{~s}(3.1 \pm 0.7$ mm/year) (IPCC, 2007; Rowley et al., 2007; Legra et al., 2008; Li et al., 2009; Islam et al., 2013; Türkeş, 2013; Simav et al., 2015). According to the Intergovernmental Panel on Climate Change (IPCC, 2007), an increase of $60 \mathrm{~cm}$ will be observed by 2100 . Sea level increases are estimated to be $1 \mathrm{~m}$ or more by 2100 according to recent studies (Nicholls and Cazenave, 2010; Kahraman and Silaydın Aydın, 2016). The sea level increase is thought to cause non-recoverable physical and socio-economic consequences in unprotected and low coastal areas. Increases in sea level generate significant physical effects such as soil loss, coastline change, coastal erosion, groundwater level rise and salinity increase in underground water resources. It has a direct effect on the climate due to the ocean-atmosphere relationship. It is estimated that there may be significant increases in meteorological and hydrological induced natural disasters (severe weather events, storms, strong precipitation, floods, etc.) as a result of sea level elevations (Rowley et al., 2007; Legra et al., 2008; Li et al., 2009; Çabuk, 2011; Islam et al., 2013; Geymen and Dirican, 2016).

Turkey, encircled by seas on three sides, is in the group of risky countries in terms of the effects that will be induced by climate change (Öztürk, 2002). The total length of the coasts of Turkey is $8483 \mathrm{~km}$ including the coastal regions of the Black Sea $(1719 \mathrm{~km})$, Marmara $(1474 \mathrm{~km})$, the Mediterranean $(2025 \mathrm{~km})$ and Aegean $(3265$ km) (SHODB, 2008; Simav et al., 2015). Approximately $3 \%$ of the coasts consisted of coastal areas with low altitude (Kahraman and Aydın, 2014). There is a total of 28 coastal cities in these regions. About $54.9 \%(44367738$ people) of Turkey's population (80810525) resides in these cities according to the census carried out in 2017 (TSI, 2017). Assets with economic value, such as fertile agricultural lands, commercial ports, and tourism facilities, are also located in coastal areas. In addition, there are also preservation areas for endangered animals (sea turtles, seals, etc.,) in coastal regions (Göksu Delta, Gediz Delta, Kızılırmak Delta, etc.) that are also rich in land and marine ecosystems (PAP/RAC, 2005). For this reason, demonstrating the physical and socio-economic effects of sea level increases in coastal areas proves to be important in long-term coastal area planning, coastal management and decision-making processes (Dasgupta et al., 2007; Gazioğlu et al., 2010).

Global warming and climate change issues, which occupy a wide coverage in the world agenda, are also important followed in scientific researches. Some studies are available on national and local levels in Turkey on 
the impacts of sea level increases (Demirkesen et al., 2007, 2008; Karaca and Nicholls, 2008; Kuleli, 2010; Alpar, 2009). In literature, there are also local and foreign studies on monitoring the effects of sea level rise by using GIS technologies (Tabak, 2006; Yönten, 2007; Sefercik, 2007; Karaca and Nicholls, 2008; Düzgüneş and Balık, 2008; Saygıl1, 2008; Karataş, 2008; Ertop, 2009; Yastıklı and Esirtgen, 2011; Simav and Şeker, 2013; Türkeş et al., 2013; Geymen et al Dirican, 2016). Sea level changes due to global warming in the coasts of Turkey were generally examined in these studies. Temperatures in Turkey continue to rise according to the initial assessments. This increase is more evident in recent years. It was determined that snow melting started earlier and the currents in snow-fed rivers were shifted earlier due to the increase in temperature. Therefore, it is of great importance to first to reveal the general risk status of the coastal areas and to carry out an analysis for all coastal areas. In this study, the risky areas that will be submerged due to sea level rise were determined by using spatial analysis in GIS. Thus, contribution to the creation of the necessary strategies was intended by determining the potential impact of climate change on coastal regions of Turkey.

In this study, extent of potential inundation and its impact on land-cover and population within a GIS environment by addressing the following four questions were assessesed:

- Where are the potentially inundated areas in Turkey?

- How large are the potentially inundated areas along the coastal line of Turkey?

- What types of land-cover, and how much of each type, are potentially inundated?

- How much of population would be impacted by potential inundation?

\section{Study Area}

Turkey is located between $26^{\circ}-25^{\circ}$ East Longitude and $36^{\circ}-42^{\circ}$ North Latitude, and at the crossroads of the Asia, Arica and Europe. Its total land area is $779452 \mathrm{~km}^{2}$. Its coastline is $8483 \mathrm{~km}$ long (SHODB, 2008; Simav et al., 2015) and are bordered by the Mediterranean Sea, the Black Sea, the Aegean Sea, and the Marmara Sea, which is connected to the Black Sea by the Bosphorus Strait and to the Aegean Sea by the Dardanelles Strait (Figure 1).

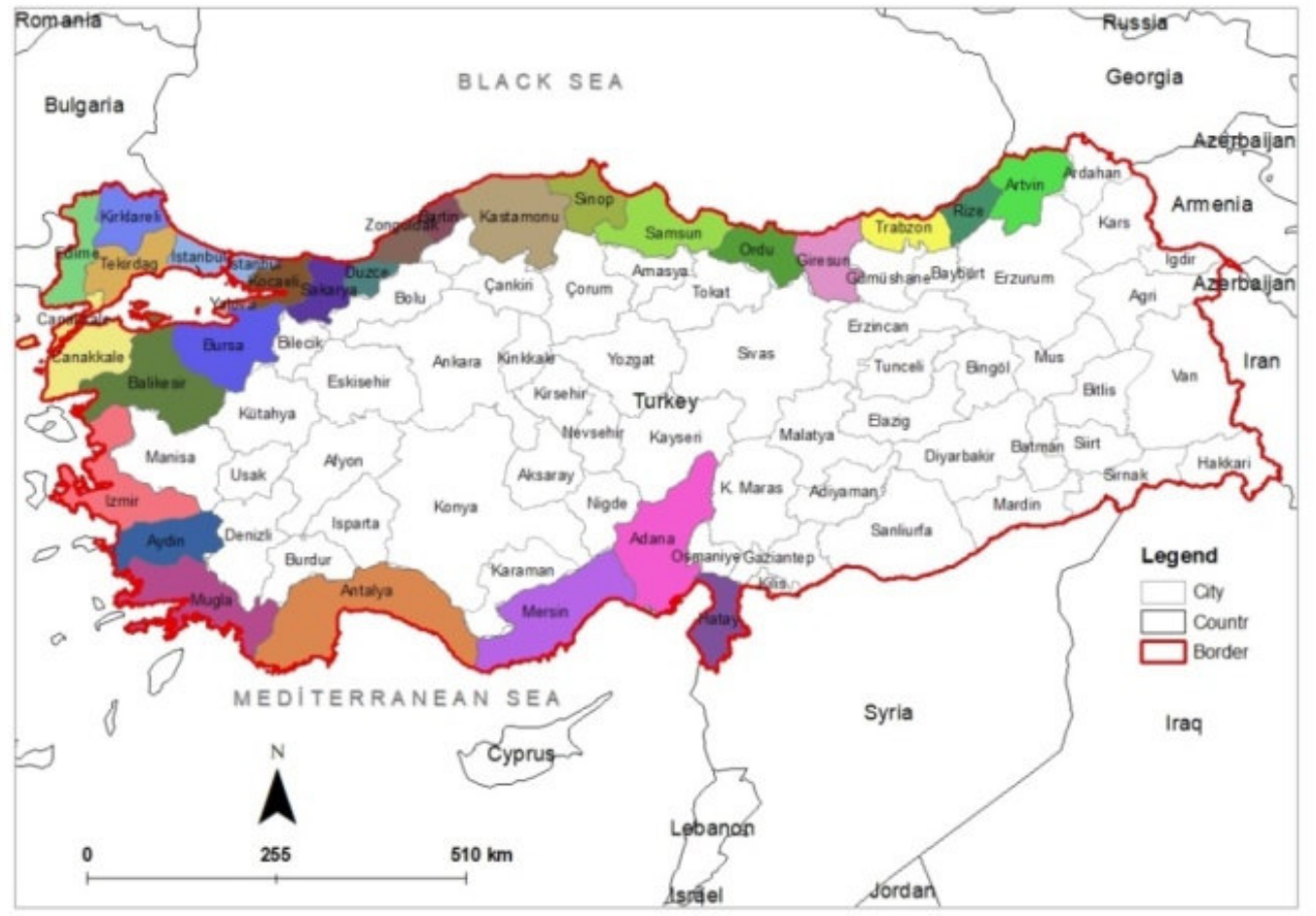

Figure 1. Study Area And Coastal Cities of Turkey

\section{Methodology And Data}

Areas under 10 meters-level are most vulnerable to sea level rise. Lower slopes areas a greater increase in flood risk due to sea level rise than steeper slopes (Nicholls et al., 1999; Kuleli et al., 2009). The increase of temperature and rise in water level will bring many socio-economic impacts on the coasts of Turkey that is encircled by seas on its sides (Türkeş, 2007). Considering that the magnitude of this effect can be calculated through possible scenarios, the first method that comes to mind will be Geographic Information Systems (GIS) (Erdoğan, 2007; Li et al., 2009). In the study GIS model was used by using spatial coastal data combined with common sea level rise projections. GIS data model and procedures were given in Figure 2.

The SRTM digital data was used (NASA, 2018). The SRTM $30 \mathrm{~m}$ DEM have a resolution of 30 meters at the 
equator. As a software Global Mapper software was used to process raster data like SRTM data. In order to create GIS database point and region vector data are used. The point vector data are settlements and cities. The region vector data are districts and boundary. City, district and settlement population was obtained from Turkish Statistical Institute census (TSI 2018).

Geographic Information System (GIS) analyses were developed to address the research questions. First, Potential Inundation Areas (PIAs) were delineated based on a global DEM. The total surface area of the PIAs, surface area of specific land-cover types, and population at risk within the PIAs were then calculated. Surface areas of land-cover types in the Potential Inundation Areas (PIAs) were calculated in a two-step. First step, the cell-surface-area layer was overlaid with the PIA layer. Next step, the sub-total area of each land-cover type in the PIAs was obtained through the zonal summary function in the GIS, where the land-cover layer was the zone layer and the overlaid layer was the value layer. Population in the PIAs was calculated in a similar manner to landcover using the zonal summary function in the GIS. As the following steps were implemented in a GIS raster analysis framework.

1. DEM cells were selected that adjacent to sea.

2. DEM cells were selected that have an elevation at or below projected sea level rise increment.

3. Coincidence of selected cells and convert to ocean were find.

4. Potential inundation zone layer by selecting cells that were land but are now considered to be sea was created .

5. Existing inland water from the potential inundation zone was subtracted.

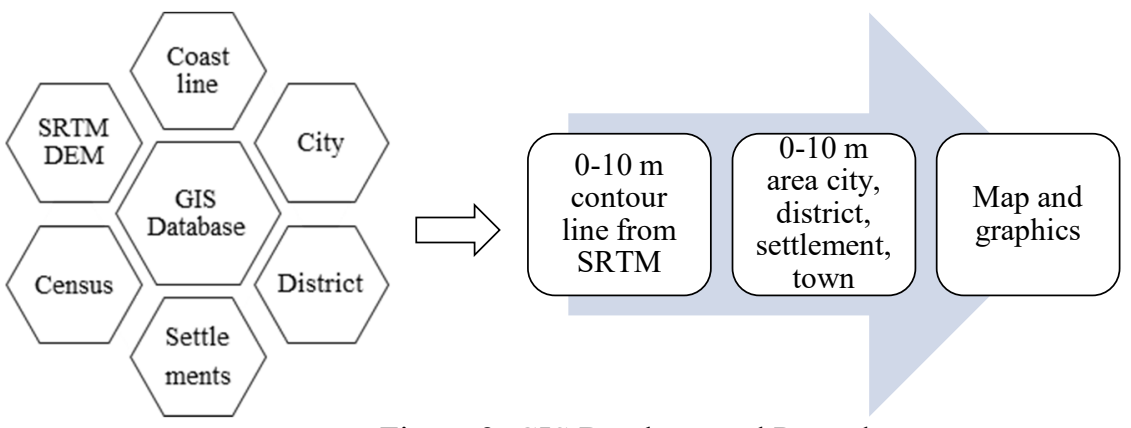

Figure 2. GIS Database and Procedures

\section{Analysis Results And Discussion}

In the study, the risky areas that would be flooded due to sea level change were identified by using spatial analysis at GIS. Turkey is highly vulnerable to sea-level rise. 28 coastal cities, 190 districts and 181 villages or towns are located in the area below $10 \mathrm{~m}$ contour line. The total population of these cities are 44367738 . The number of districts on the coastal regions (Black Sea, Marmara, Aegean, Mediterranean) are 196. The total population of these districts are 22177259. The number of population that will be primarily affected by a possible sea level rise is 22177259 . About $3 \%$ of Turkey's coasts consist of low-altitude coastal areas. It can be noticed by looking at the sea level rise scenarios that the coastal cities are under threat (Figure 3; Table 1).

Table 1. Datasheet of Mock-up Test

\begin{tabular}{llll}
\hline Cities & Population & Cities & Population \\
\hline Adana & 2216475 & İzmir & 4279677 \\
Antalya & 2364396 & Kastamonu & 372373 \\
Artvin & 166143 & Kirklareli & 356050 \\
Aydın & 1080839 & Kocaeli & 1883270 \\
Bartın & 193577 & Muğla & 938751 \\
Balıkesir & 1204824 & Ordu & 742341 \\
Bursa & 2936803 & Rize & 331041 \\
Çanakkale & 530417 & Sakarya & 990214 \\
Düzce & 377610 & Samsun & 1312990 \\
Edirne & 406855 & Sinop & 207427 \\
Giresun & 437393 & Tekirdağ & 1005463 \\
Hatay & 1575226 & Trabzon & 786326 \\
Mersin & 1793931 & Yalova & 251203 \\
İstanbul & 15029231 & Zonguldak & 596892
\end{tabular}

Black Sea, Marmara, Aegean, and Mediterranean regions have significant values for agricultural production and population. For example, over 40 million people live in these areas (Figure 3; Table 2). 


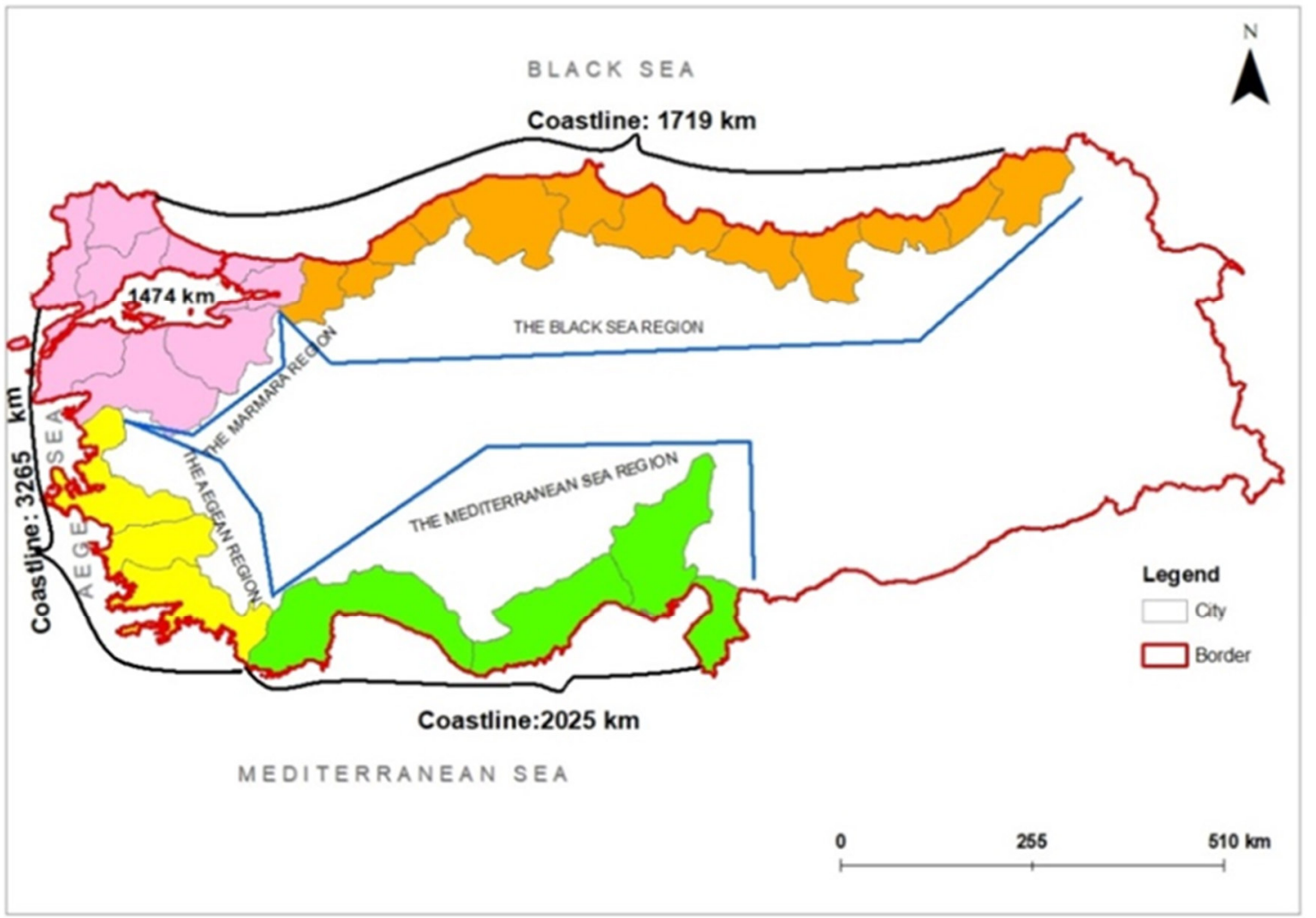

Figure 3. Coastal Areas Below 10 Meters Elevation Above The Present Mean Sea Level

Table 2. Turkey Coastal Regions and Populations (2017)

\begin{tabular}{cccccc}
\hline Region & City & Districts & $\begin{array}{c}\text { Settlements } \\
\text { (within 0-10m) }\end{array}$ & $\begin{array}{c}\text { Populations } \\
\text { (City) }\end{array}$ & $\begin{array}{c}\text { Population within } \\
\text { 0-10m (Districts) }\end{array}$ \\
\hline Black Sea & 12 & 63 & 51 & 6514327 & 3167815 \\
Marmara & 9 & 69 & 32 & 23604116 & 11857855 \\
Aegean & 3 & 31 & 38 & 6299267 & 3780995 \\
Mediterranean & 4 & 27 & 60 & 7950028 & 3370594 \\
Total & 28 & 190 & 181 & 44367738 & 22177259 \\
\hline
\end{tabular}

Coastal erosion, flooding and inundation along Turkish coastal lines are important problems, particularly in the Aegean, Mediterraneanand and Black sea region within important agricultural deltaic plains (Çukurova, Çarşamba and Bafra Plain etc.) Touristic coastal cities, many cultural sites and ancient cities in Mediterranean and Aegean region under threat which will cause by sea level rise. Deltaic coasts are expected to undergo shoreline change due the rising sea level. That will result in increased flooding across the delta plain causing interruption of agricultural activity (Figure 4).

Figure 4 shows a map of the risk value for the Turkish coast. According to the sea level change scenarios in coastal cities in Turkey, the ratio of the area affected by the water level changes in Adana $\left(13844 \mathrm{~km}^{2}\right)$, Izmir $\left(11891 \mathrm{~km}^{2}\right)$, Samsun $\left(9725 \mathrm{~km}^{2}\right)$, and Edirne $\left(6145 \mathrm{~km}^{2}\right)$ provinces that have low-elevation terrain and large delta areas seems to be more than other cities (Figure 4; Table 3). Potential inundation at 10 meters in 5 selected regions of the Turkey is shown in Figure 4 and Table 3.

Notice the concentrations of potential inundation surrounding river deltas, and low-lying coastal plains. 


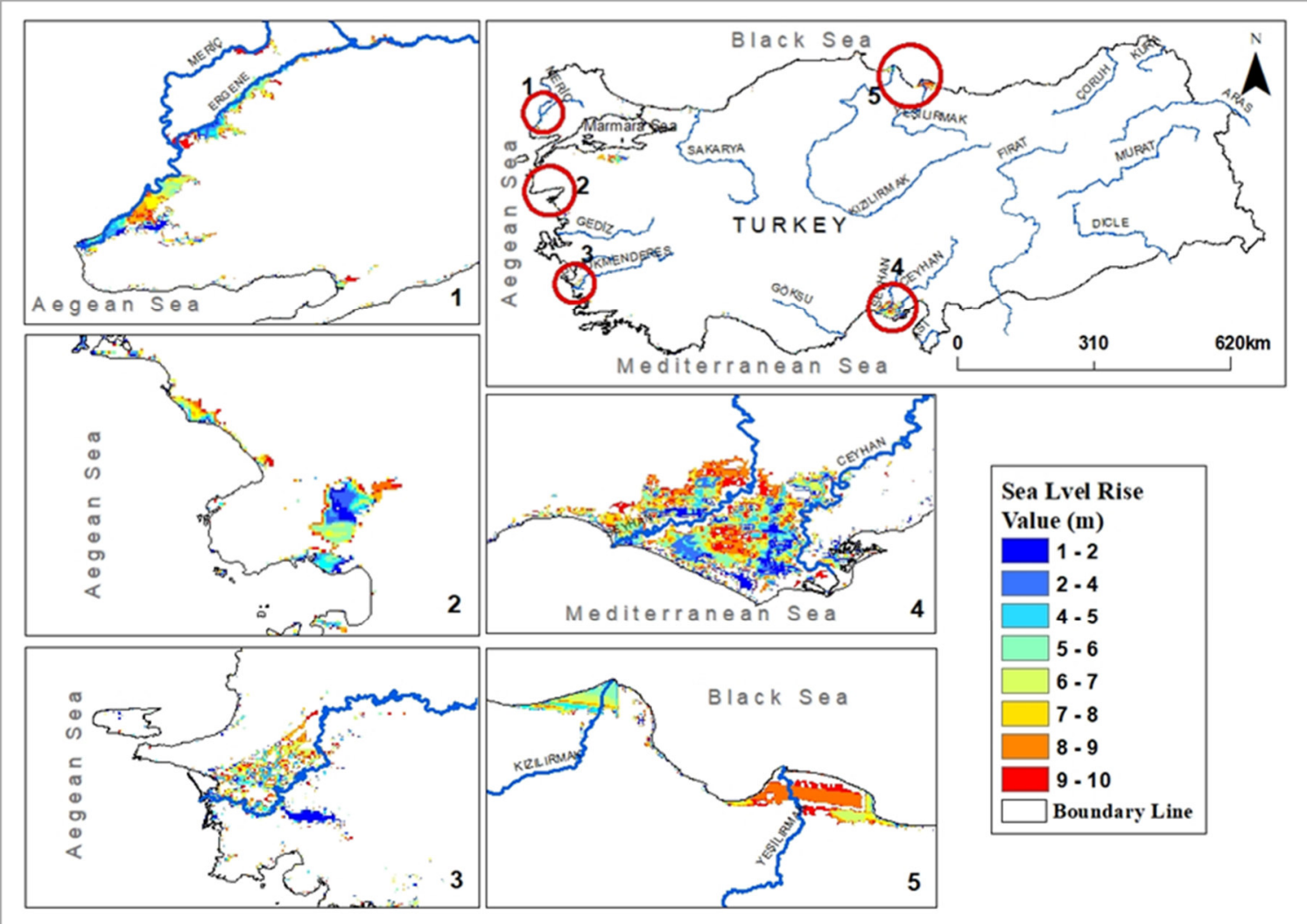

Figure 4. Risk Areas And Potantial Land Loss in The Turkey Coasts

Table 4, Figure 5 show the effects of sea level changes in Turkey in general and the figures corresponding to the ratio of these spatial effects to the population of the coastal cities in Turkey. Population at risk due to potential inundation ranges from 214130 people at the one meter increment to 1970378 people at the ten meter increment. Total area of Potentially Inundated Areas (PIAs) ranges from $1613.75 \mathrm{~km}^{2}$ at the one-meter increment to $9455 \mathrm{~km}^{2}$ at the ten-meter increment. The percentage of land area of PIAs for each of the sea level rise increments is also shown in Table 3.

Table 3. Total Area of Potentially Inundated Areas (PIAS), Percentages of Land Area of PIAS, Population in PIAS, And Its Percentages of Total Population or Sea Level Rise From One To Ten Meters

\begin{tabular}{|l|l|l|l|l|l|l|}
\hline $\begin{array}{l}\text { Sea } \\
\text { Level } \\
\text { Rise }(\mathrm{m})\end{array}$ & $\begin{array}{l}\text { Inundated } \\
\text { Area }\left(\mathrm{km}^{2}\right)\end{array}$ & $\begin{array}{l}\% \text { of Total } \\
\text { Area }\end{array}$ & Population & $\begin{array}{l}\text { Population } \\
\text { (millions) }\end{array}$ & $\begin{array}{l}\text { Percentage of } \\
\text { the total } \\
\text { population }\end{array}$ & $\begin{array}{l}\text { Percentage } \\
\text { of the Area } \\
\text { of Intrest }\end{array}$ \\
\hline 1 & 1613.75 & 0.203392101 & 214130 & 0.21413 & $2.67663 \mathrm{E}-07$ & $9.78 \mathrm{E}-07$ \\
\hline 2 & 2544.25 & 0.320669467 & 394312 & 0.394312 & $4.9289 \mathrm{E}-07$ & $1.8 \mathrm{E}-06$ \\
\hline 3 & 3307.75 & 0.416898665 & 525282 & 0.525282 & $6.56603 \mathrm{E}-07$ & $2.4 \mathrm{E}-06$ \\
\hline 4 & 4097.25 & 0.516404824 & 715195 & 0.715195 & $8.93994 \mathrm{E}-07$ & $3.27 \mathrm{E}-06$ \\
\hline 5 & 4944.5 & 0.623189616 & 875021 & 0.875021 & $1.09378 \mathrm{E}-06$ & $4 \mathrm{E}-06$ \\
\hline 6 & 5817 & 0.73315684 & 1079957 & 1.079957 & $1.34995 \mathrm{E}-06$ & $4.93 \mathrm{E}-06$ \\
\hline 7 & 6604.75 & 0.832442434 & 1279698 & 1.279698 & $1.59962 \mathrm{E}-06$ & $5.85 \mathrm{E}-06$ \\
\hline 8 & 7516.25 & 0.947325098 & 1483562 & 1.483562 & $1.85445 \mathrm{E}-06$ & $6.78 \mathrm{E}-06$ \\
\hline 9 & 8588.25 & 1.082436691 & 1751672 & 1.751672 & $2.18959 \mathrm{E}-06$ & $8 \mathrm{E}-06$ \\
\hline 10 & 9455 & 1.191679202 & 1970378 & 1.970378 & $2.46297 \mathrm{E}-06$ & $9 \mathrm{E}-06$ \\
\hline
\end{tabular}




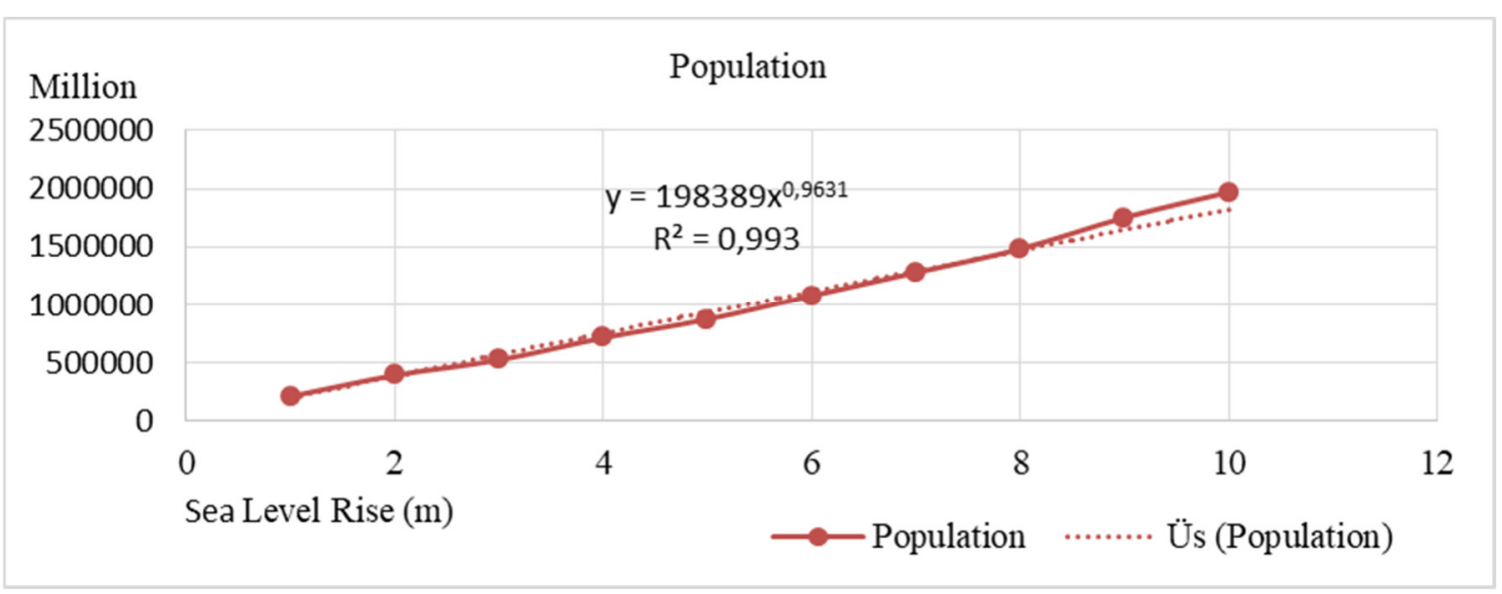

Figure 5. Population at Risk

Among the nine land-cover types in Potentially Inundated Areas (PIAs), croplands, permanent wetlands and grasslands account for a big part of increments of sea level rise (Table 4). The percentage of crop land lost increases steadily as sea level rise increases. Permanent wetlands is one of the most importand land-cover type in which the percentage lost decreases with increasing sea level rise. Percentages of land-cover types in the PIAs for each sea level rise projection are shown in Figure 6.

Table 4. Sub-Total Area of Potential Inundation By Ten Aggregated Land Cover Types

\begin{tabular}{|c|c|c|c|c|c|c|c|c|c|c|}
\hline \multicolumn{11}{|c|}{ Sub-total Area $\left(1000 \mathrm{~km}^{2}\right)$} \\
\hline Land-cover & $1 \mathrm{~m}$ & $2 \mathrm{~m}$ & $3 \mathrm{~m}$ & $4 \mathrm{~m}$ & $5 \mathrm{~m}$ & $6 \mathrm{~m}$ & $7 \mathrm{~m}$ & $8 \mathrm{~m}$ & $9 \mathrm{~m}$ & $10 \mathrm{~m}$ \\
\hline Water & 0,0021689 & 0,0027513 & 0,0034767 & 0,0042712 & 0,0047022 & 0,0044697 & 0,0042772 & 0,0041577 & 0,0039298 & 0,004019 \\
\hline AllForest & 0,0040279 & 0,0048148 & 0,0102789 & 0,011166 & 0,0105673 & 0,0099708 & 0,0097278 & 0,0092134 & 0,0085582 & 0,0084082 \\
\hline Shrublands & 0,015182 & 0,0231895 & 0,0308367 & 0,0317286 & 0,0310952 & 0,0376053 & 0,0375109 & 0,0368867 & 0,048089 & 0,0502644 \\
\hline Savannas & 0,0698683 & 0,0932495 & 0,1095155 & 0,1175789 & 0,1230155 & 0,1234313 & 0,1241152 & 0,1230334 & 0,1242686 & 0,1257007 \\
\hline Grasslands & 0,0642912 & 0,0711408 & 0,0684 & 0,0668741 & 0,0625442 & 0,0606412 & 0,058632 & 0,0557126 & 0,0523098 & 0,050238 \\
\hline Permanent wetlands & 0,095275 & 0,1255773 & 0,1602298 & 0,2119104 & 0,2645869 & 0,3042806 & 0,3343806 & 0,3528688 & 0,3688761 & 0,3849286 \\
\hline Croplands & 0,0410534 & 0,0452982 & 0,05147 & 0,055281 & 0,0584488 & 0,05918 & 0,0603732 & 0,0604025 & 0,0603732 & 0,0597303 \\
\hline Urban and built-up & 0,0017041 & 0,0023583 & 0,0047615 & 0,0065288 & 0,0088482 & 0,0112601 & 0,0120368 & 0,012606 & 0,0233167 & 0,0272871 \\
\hline Snow/ice/Barren' & 0,7064291 & 0,6316203 & 0,5610309 & 0,4946611 & 0,4361917 & 0,3891611 & 0,3589462 & 0,3451189 & 0,3102786 & 0,2894236 \\
\hline
\end{tabular}

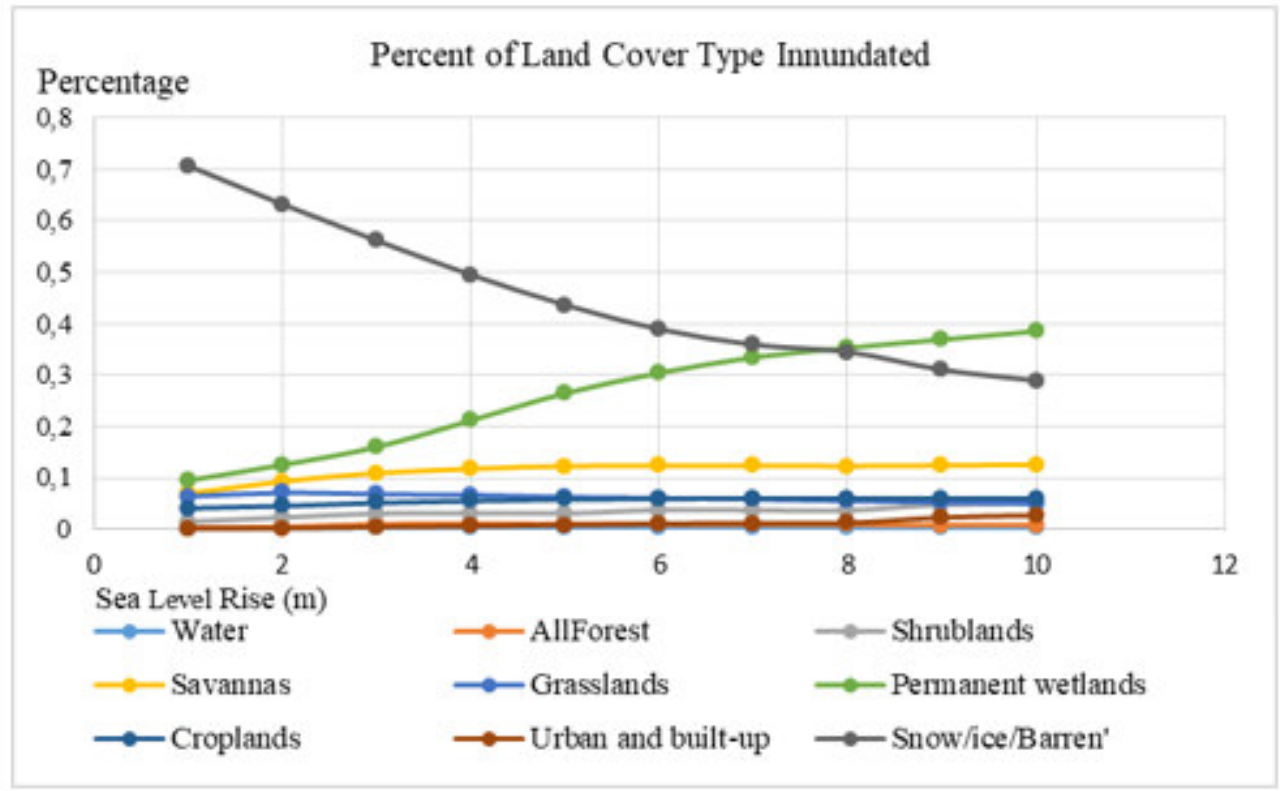

Figure 6. Percentages of Sub-Total Area of Each Land-Cover Type in The PIAS.

\section{Conclusion}

It is thought that glaciers will continue to melt with the warming of the oceans in the future and sea level rises may occur due to global warming. Risky regions will occur in the coasts of Turkey as a result of the possible future changes in sea levels due to climate change. In this study, the risky regions, which will be formed, were obtained 
by entering the water level values that were desired to be increased from sea level by using spatial analysis in Geographic Information Systems.

In the study primarily, after susceptible areas were delineated, they were estimated that the size of the areas is between $1613.75 \mathrm{~km}^{2}$ (one meter) to $9455 \mathrm{~km}^{2}$ (ten meters). Population in the susceptible areas was estimated to range from 214130 ( 1 meter) to 1970378 (10 meters) people. Among the nine land-cover types in the susceptible areas permanent wetlands, croplands and grassland account for a big part of increments of sea level rise.

28 provinces that were affected by the spatial change located within the Mediterranean, Marmara, Aegean and Black Sea regions that possess coastal lines had been identified. The provinces that will be affected the most by the spatial changes are Adana, Edirne, Izmir and Samsun. These spatial changes, which are expected to happen, will affect the provinces with high population, agriculture and industrial density. The province that will be affected the most by this situation is Adana province in the Mediterranean region. The main reason behind high values of spatial changes in the province of Adana was due to the fact that it has delta and lowlands formed by the effects of large rivers of this province.

It is expected that the socio-economic effects of possible sea level changes in addition to many effects, such as decreased precipitation due to global warming and temperature increase, will be felt considering the fact that the high proportion of Turkey's population resides in coastal areas such as the Mediterranean, Marmara, Aegean and Black Sea regions. Therefore, exposing the physical and socio-economic effects of sea level increases that will occur in coastal areas is significant in long-term coastal area planning, coastal management and decision-making processes.

Sea level rise along the Turkish coast is not likely to be as significant as in other areas around the world. But there will be local vulnerability due to topography and subsidence in the area. For this reason, monitoring the main impacts of changes in the future water levels and identifying the risky areas in this way will assist urban planners and local administrators. As soon as possible, for the struggle of negative impact of sea level rise, The Ministry of Environment should declare new areas as protection zones and develop special national level environmental programs.

\section{Acknowledgments}

In this study, The Scientific and Technological Research Council of Turkey, Vice Presidency Science Fellowships and Grant Programmes Department was supported by a project number coded under the 1059B191601246. We thank the Scientific and Technological Research Council of Turkey for their contributions.

\section{References}

Çabuk, S.Ö. (2011). The evaluation of the role of economic instruments for the reduction of the greenhouse gas emissions that cause global warming: energy sector example. PhD., Ankara University, Institute of Social Sciences, Ankara, Turkey (in Turkish) pp 368.

Erdoğan, M. (2007). Investigation of digital elevation model standards according to source and quality of data and production method. PhD, İstanbul Technical University, Institute of Science and Technology, 2007, İstanbul, Turkey (in Turkish).

Ertop, G. (2009). Global warming and xeriscape planning. Ankara University, Institute of Science and Technology, Master Thesis, Ankara, Turkey (in Turkish), pp 173.

Geymen, A., Dirican, Y.A. (21016). "Analysis sea level change due to climate change using Geographical Information Systems". Electronic Journal of Map Technologies, 8(1): 65-74.

IPCC (2007). Climate change impacts, adaptation and vulnerability. Contribution of working group II to the fourth assessment report of the intergovernmental panel on climate change, Cambridge Univ. Press, Cambridge, U. $\mathrm{K}$.

Islam, M.Z., Menon, S., Li, X., Peterson, A.T. (2013). "Forecasting ecological impacts of sea-level rise on coastal conservation areas in India", Journal of Threatened Taxa, 5(9): 4349-4358, DOI: 10.11609/JoTT.o3163.4349-58.

Kahraman, D.E., Silaydın Aydın, B.M. (2016). "Determining vulnerability levels of coastal cities in morphological context against to sea level rise threat”, Turkey. TÜCAUM International Geography Symposium, 13-14 October 2016, Ankara, Turkey.

Kahraman, E.D., Aydın, M.B.S. (2014). "Determining spatial development decisions of 1/100000 scale environmental plans on coastal areas”, TÜCAUM VIII. Geography Symposium, Ankara, Turkey, pp 65-71.

Karaca, M., Nicholls, R.J. (2008). "Potential implications of accelerated sea-level rise for Turkey". Journal of Coastal Research, (24): 288-298.

Karataş, E. (2008). “Analysis of accuracy of SRTM3 digital elevation model using RTK GPS”. Master Thesis, Selçuk University, Institute of Natural and Applied Sciences, Geodesy and Photogrammetry Engineering, Konya, Turkey (in Turkish), pp 58.

Legra, L, Li, X, Peterson, T.A. (2008). "Biodiversity consequences of sea level rise in New Guinea". Pacific 
Conservation Biology, 14(3): 191-199.

Li, X., Rowley, J.R., Kostelnick, J.C., Braaten, D., Meisel, J., Hulbutta, K. (2009). “GIS analysis of global impacts from sea level rise”. Photogrammetric Engineering \& Remote Sensing, 75 (7): 807-818.

NASA (2018). The Shuttle Radar Topography Mission (SRTM). http://www2.jpl.nasa.gov/srtm/.

Nicholls, R.J., Hoozemans, F.M.J., Marchand, M. (1999). "Increasing flood risk and wetland losses due to global sea-level rise: Regional and global analysis”. Global Environmental Change, 9, S69-S87. doi:10. 1016/S0959-3780(99)00019-9.

Nicholls, R.J, Cazenave, A. (2010). "Sea-level rise and its impact on coastal zones". Science, 328(5985): 15171520.

Öztürk, K. (2002). "Global climatic changes and their probable effect upon Turkey”. Gazi University Education Faculty Journal, 22: 47-65.

Priority Actions Programme Regional Activity Centre (PAP/RAC), (2005). "Coastal area management in Turkey". Priority Actions Programme Regional Activity Centre, Split.

Rowley, R.J., Kostelnick, JC, Braaten, D., Li, X., Meisel, J. (2007). "Risk of rising sea level to population and land area. Eos", Transactions, American Geophysical Union, 88(9): 105-107.

Sağlam, N.E., Düzgüneş E., Balık, İ. (2008). "Global warming and climatic changes”. E.U. Journal of Fisheries and Aquatic Sciences, (25): 89-94.

Saygill, A. (2008). Examining the accuracy of the numerical elevation models obtained from the SRTM (Shuttle Radar Topography Mission) data. Master Thesis, Yildiz Technical University, Institute of Science and Technology, İstanbul, Turkey (in Turkish) pp 99.

Sefercik, U.G. (2007). "Production and accuracy evaluations of SYM with radar interferometry technique". UCTEA Chamber of Survey and Cadastre Engineering, 11 Turkey Map, Scientific and Technical Conference, 2-6 April 2007, Ankara, Turkey.

Turkey Naval Forses Office of Navigation, Hydrography and Oceanography (ONHO) (2008). Coastal Survey Information.

Simav, Ö., Şeker D.Z. (2013). "Determining the endangered fields of turkish coasts with coastal vulnerability index", UCTEA Chamber of Survey and Cadastre Engineering Geographical Information Systems Congress, 11 -13 November 2013, Ankara, Turkey.

Simav, Ö., Şeker, Z.D, Tanık, A., Gazioğlu, C. (2015). "Determining the endangered fields of Turkish coasts with coastal vulnerability index". Journal of Map, Issue 153.

Tabak, P. (2006). Investigation of solutions in residential architecture against the rising waters due to global warming problems. Master Thesis, Yıldız Technical University, Graduate School of Natural and Applied Sciences, İstanbul, Turkey (in Turkish), pp 72.

Türkeş, M. (2007). "What is climate change? Basic definition, causes, observed and predicted results of climate change”, I. Turkey Climate Change Congress TCCC 2007, 11-13 April, İstanbul.

Türkeş, M., Şen, Ö.L., Kurnaz, L., Madra, Ö., Şahin, Ü. (2013). "Recent developments in climate change: IPCC 2013 report". Sabancı University, İstanbul Political Center, 2013, İstanbul.

Turkish Statistical Institute Institute (TSI). (2018). with Statistics 2017 - Personal Webpage. Accessed on 10 October $2018 \mathrm{http}: / /$ www.tuik.gov.tr.

Yastıkl1, N., Esirtgen F. (2011). "Quality assessment and accuracy analysıs of digital elevation models", UCTEA Chamber of Survey and Cadastre Engineering, 13. Turkey Scientific and Technical Conference, 18-22 April 2011, Ankara, Turkey.

Yönten, A. (2007). "Reducing global warming policies: An approach to Turkey”. Master Thesis, Dokuz Eylül University, Social Sciences Institute, İzmir, Turkey (in Turkish), pp 171. 